\title{
Mısır Hanefiliği: Memlükler Dönemi Hanefi Fıkıh Düşüncesi, Dr. Bekir Karadağ (Astana Yayınları), s. 216. ISBN: 978-625-7890-18-2
}

\author{
Mustafa $\operatorname{Taş}^{1}$ (C)
}

Mustafa Taş (Araş. Gör.), Niğde Ömer Halisdemir Üniversitesi, İslami Illimler Fakültesi Temel İslam Bilimleri Bölümü, Fıkıh Anabilim Dalı, Niğde, Türkiye

E-posta: mtas2019@ogr.iu.edu.tr ORCID:000-0002-8556-9479

Başvuru/Submitted: 31.08.2020 • Revizyon Talebi/Revision Requested: 03.09.2020 • Son Revizyon/Last Revision Received: 09.09.2020 • Kabul/Accepted: 11.09 .2020

Atıf/Citation: Taş, Mustafa. Mısır Hanefiliği: Memlükler Dönemi Hanefi Fıkıh Düşüncesi, Dr. Bekir Karadağ (Astana Yayınları), s. 216. Islam Tetkikleri DergisiJournal of Islamic Review 10/2, (Eylül 2020): 687-691. https://doi.org/10.26650/iuitd.2020.788375

Dört büyük Sünnî fikıh mezhebinden biri olan Hanefîlik hicrî ikinci yüzyılda Ebû Hanîfe ve öğrencilerinin görüşleri doğrultusunda Irak bölgesinde teşekkül etmiş ve daha sonra birçok coğrafyaya yayılmıştır. Buna bağlı olarak mezhep içerisinde Irak, Mâverâünnehir, Mısır, Osmanlı ve Hint alt kıtası Hanefîliği gibi pek çok bölgesel alt ekol gelişmiştir. Bu alt ekollerden biri olan Mısır Hanefîliği Abbâsîler tarafından bölgeye Hanefî kadıların atanmasıyla başlamış, Zengîler ve Eyyûbîler döneminde de gelişimini sürdürerek Memlükler ile oluşumunu tamamlamıştır. Bu bağlamda tanıtımını yapacağımız, Muş Alparslan Üniversitesi İslam Hukuku kürsüsünde öğretim üyesi olan Dr. Bekir Karadağ tarafindan telif edilen Mısır Hanefiliği: Memlükler Dönemi Hanefi Fıkıh Düşüncesi başlıklı eser Hanefî mezhebinin bir alt ekolü olarak Mısır Hanefîliğini incelemektedir.

Bir giriş ve üç bölümden oluşan çalışmanın giriş bölümünde Abbâsîlerden Memlüklere kadar Hanefî̀ mezhebinin Mısır'daki avantürü ile mezhebin tarihsel dönemleri ve Hanefî fakihlerin hadisle olan ilişkileri ele alınmış, birinci bölümde mezhepteki alt ekoller, ekolleşme sebepleri, Mısır Hanefiliğinin mahiyeti ve ortaya çıkış nedenleri tetkik edilmiştir. İkinci bölümü Mısır Hanefiliğinin önemli temsilcilerine ve temel özelliklerine ayrılan çalışmanın üçüncü ve son bölümünde ise Mısır Hanefîliğinin Osmanlı dönemi Mısır-Şam, Anadolu ve Hint alt kıtasına etkileri üzerinde durulmuştur. 
Giriş bölümü siyasi ve sosyo-kültürel faktörlerin toplumların düşünce dünyasını nasıl şekillendirdiği ile başlayan çalışmada Memlük öncesi Zengîler ve Eyyûbîler ile Memlükler dönemi Mısır fikrî hayatının oluşumunda etkili olan; Moğol istilası ile Doğu İslam topraklarında yaşayan pek çok âlimin bu coğrafyaya göç etmesi, Batı'da başlayan Reconquista ile Endülüs Emevî devletinin inhitat sürecinin başlaması ve Şia tehlikesinin zuhur etmesi şeklinde başlıca üç etmen zikredilmektedir. Daha sonra Mısır'da Hanefîliğin yayılışı bölgede hüküm süren devletler bazında dönemlere ayrılmış ve Mısır'ın Hanefî mezhebi ile ilk karşılaşmasının Abbâsîler tarafından tayin edilen İsmâil b. Elyesa el-Kindî (ö. 164/781) ve Bekkâr b. Kuteybe (ö. 270/884) gibi Hanefî kadılar ve Abdullah b. Ferruh (ö. 176/792) gibi fakihler eliyle gerçekleştiği belirtilmiştir. Buna rağmen bu dönemde Hanefîliğin bölgede yaygın hale gelmemesinin nedeni olarak ise İmam Şâfiî'nin Mısır'da bıraktığı miras, İmam Mâlik'in talebelerinin bölgedeki etkili çalışmaları ve zamanla Hanefî kadı atama uygulamasının kısmen terk edilmesi gösterilmiştir. Çalışmada Fâtımîler döneminde bölgedeki Sünnî mezheplerin, hususen de Fâtımîlerin siyasi rakibi olan Abbâsîlerin resmî mezhebi mesabesindeki Hanefîliğin sıkıntılı bir süreç geçirdiği ifade edilmiştir. Bu durumun Zengîler ve Eyyûbîler dönemlerinde tersine döndüğü, bu iki devletin hâkimiyetinde bölgede Hanefî̀ tedrisatı için medreselerin açıldığg, Hanefî fakihlere kadılık ve müderrislik görevleri verilmesiyle Hanefîliğin tekrar yayılmaya başladığı belirtilmektedir. Hanefîliğin Memlükler döneminde Mısır ve Şam havzasında altın çağını yaşadığı ileri sürülen eserde bu dönemde Hanefî̀ mezhebi ile ilgili yaşanan gelişmeler; çoğunluğu Türk olan Memlüklerin bundan ötürü Hanefîliği benimsemesi, Hanefî fikhı eğitimi veren medrese ve kurumların artmaya başlaması, Hanefîliğin devletin resmî mezheplerinden biri haline gelmesi ve bu dönemde Hanefî mezhebinde etkin pek çok fakihin görülmesi şeklinde sıralanmaktadır.

Çalışmanın giriş bölümünde ayrıca Hanefî mezhebi için yapılan dönemlendirmeler, Hanefî fakihlerin hadise yaklaşımları bağlamında değerlendirilmiştir. Bu meyanda müellif; mutlak müçtehit-mezhepte müçtehit-ashâbü’t-tahrîc-ashâbü’t-tercîh-ashâbü’t-temyîz, mütekaddimînmüteahhirîn, selef-halef-meşayih ve selef-halef-müteahhirîn-klasik sonrası şeklinde yapılan dönemlendirmeleri zikretmekte ve bunlardan sonuncusunu esas aldığını ifade etmektedir. Daha sonra bu dönemlerin tanımları yapılmış ve selef döneminin Ebû Hanîfe'den İmam Muhammed'e, halef döneminin İmam Muhammed'den Halvânî’ye (ö. 452/1060), müteahhirîn döneminin Halvânî’ den Hâfızüddin el-Buhârî’ye (ö. 694/1294) kadar olan sürece, klasik sonrası dönemin ise Hâfızüddin el-Buhârî sonrasına tekabül ettiğini belirtilmiştir. Selef dönemi Hanefî fakihlerin hadisle olan ilişkileri bağlamında, mezhebin kurucu imamlarının -özellikle de Ebû Hanîfe'nin- hadis ile iştigal ettiklerinin, diğer mezhep müntesiplerinin bu imamların hadis konusunda eksik olduklarına yönelik tenkitlerinin haksız olduğunun gösterildiği eserde yazar halef döneminde de Tahâvî (ö. 321/933), Kerhî (ö. 340/952), Cessâs (ö. 370/981) ve Kudûrî (ö. 428/1037) gibi âlimler tarafından hadis hassasiyetinin devam ettiğini aktarmaktadır. Çalışmada, müteahhirînin hadis konusunda mezhep içerisinde en zayıf halka olduğunu söylemenin mümkün olduğu belirtilmiştir. Bunu teyit sadedinde daha sonraki dönemlerde yaşayan bazı âlimlerin 
müteahhirîn hadis çalışmalarının yetersiz olduğuna dair tespitleri nakledilmiştir. Müellif klasik sonrası dönem Hanefîlerini hadis konusunda önceki dönemler gibi zayıf görmekle beraber Mısır ve çevresinin ise hadis çalışmaları bakımından bir uyanışa tanıklık ettiğini ileri sürmektedir.

Birinci bölümünde Hanefî mezhebinde alt ekollerin ele alındığı çalışmada bu ekollerden Irak ve Mâverâünnehir hakkında kısa bir değerlendirme yapıldıktan sonra ekolleşme sebepleri; ilmî muhitin farklılığı, hoca talebe ilişkisi, rivayet geleneği ve hukuki istikrar ihtiyacı olarak tadat edilmiştir. Bunu müteakiben Mısır Hanefiliği bahsinde başka araştırmacıların dönemi belirtmede kullandığı "muhaddis fukahâ ekolü" ya da "hadisçi Hanefîler" ifadeleri yerine "Mısır Hanefîleri” şeklindeki tesmiyenin sınırları daha net bir şekilde dermeyan ettiği nedeniyle tercih edildiği izah edilmiştir. Mısır Hanefîliğinin ekolleşme sürecinin ve bu süreçte etkili olan unsurların ele alındığ Mısır Hanefîliğinin mahiyeti başlığında ayrıca hoca talebe ilişkisinin ekolleşme üzerindeki etkileri doğrultusunda Mısır Hanefîliği için önemli görülen isimlere yer verilmiştir. Bu bağlamda zikredilen isimler Ebû Hanîfe, Tahâvî ve Serûcî (ö. 710/1310) şeklinde olup bunun gerekçesi ise Ebû Hanîfe'nin mezhep imamı, Tahâvî'nin Mısır'daki ilk hadis otoritesi, Serûcî’nin ise pratik anlamda Mısır Hanefîliğinin ilk temsilcisi olması şeklinde açıklanmıştır. Daha sonra Mısır Hanefîliği ve mezhebin diğer ekolleri arasında mukayeselerde bulunarak benzer ve farklı noktalara temas eden müellif, nihayetinde Mısır Hanefîliğinin nevi şahsına münhasır bir ekol olduğunu derkâr etmektedir. Mısır Hanefîliğinin mahiyetinin ardından Karadağ ekolün ortaya çıkış sebepleri üzerinde durmaktadır. Ekolün ortaya çıkış sebeplerinden ilki olarak döneme hâkim olan siyasi düşüncenin gösterildiği eserde bu durum o dönemde mevcut olan Şia tehdidinin mezhepleri ortak hareket etmeye sevk ettiği, bu birliktelik düşüncesinin de mezhepler üstü bir strateji oluşturma ve Sünnîliği bir üst kimlik haline getirme gereğine bağl1 olarak Hanefîleri hadise tevcih ettiği şeklinde yorumlanmıştır. Zengîler, Eyyûbîler ve Memlükler tarafından kurulan medrese ve dârülhadis gibi eğitim kurumları da Mısır Hanefîliğinin ortaya çıkma sebebi olarak görülmüştür. Nitekim Hanefî fakihler gerek hoca gerekse de öğrenci olarak bu kurumlarda bulunmuş ve hadisle iştigal etmişlerdir. Diğer bir sebep olarak ise başta Moğol istilası olmak üzere Hanefî fakihlerin Batı'ya, Mısır ve Şam bölgesine göç etmelerine neden olan sosyal olaylar gösterilmiştir. Bu göçler neticesinde Hanefî fakihler diğer mezheplerin müntesipleri ile mülaki olmuş ve bu da mezhep birikimini diğer mezheplere karşı hadis açısından kritik etme ihtiyacını doğurmuştur. Mısır Hanefîliğinin oluşumundaki diğer iki sebep olarak ise Sünnî mezheplerin yakınlaşması ve diğer mezheplerin rolü gösterilmiştir. Diğer mezheplerin rolünün iki açıdan düşünülmesi gerektiğini ifade eden müellife göre bunlardan birincisi Hanefî fakihlerini hadis çalışmalarına icbar eden diğer mezheplerin hadis konusunda Hanefîlere yönelttikleri eleştirilerdir. İkincisi ise diğer mezheplere mensup âlimlerin Hanefî fakihlerle hoca talebe ilişkisi kurarak onlara hadis sahasındaki eksiklerini gidermede yardımcı olmalarıdır. Öte yandan Mısır'ın o dönemki kozmopolit yapısı, dört mezhebin bir arada yaşıyor olması gibi durumlar Sünnî mezheplerin yakınlaşmasına sebep olmuş, buna bağlı olarak mezhepler arasında yaşanan etkileşim de Hanefîlerin hadise yönelimi ile neticelenmiştir. Eserde Mısır 
Hanefîliğinin ortaya çıkmasında etkili olan son sebep olarak ise temel hadis kaynaklarının otorite haline gelmesiyle Hanefî fakihlerin eserlerini bu veçheden bir tenkite tâbi tutmalarını gerektiren teorik ihtiyaç zikredilmiştir.

Mısır Hanefîliğinin önemli isimleri ve ekolün temel özelliklerinin konu edildiği çalışmanın ikinci bölümünde öncelikle Dımaşk'ta yaşayan ve Nuriye Medresesi'nde müderrislik yapan Hasîrî (ö. 636/1238), önceleri Hanbelî iken Hanefî̀ mezhebine geçen ve Dımaşk’ta Şibliye, Bedriyye, Müstansıriyye medreselerinde müderrislik yapan tarihçi, âlim ve meşhur vâiz Sıbt İbnü'l-Cevzî (ö. 654/1256) ve Menbicî (ö. 686/1287) gibi Mısır Hanefîliğinin öncüleri kabul edilen âlimlerin hayatları, eserleri ve Mısır Hanefîliği ile olan ilişkileri incelenmektedir. Derakap Mısır Hanefîliğine mensup olan fakihlerin hadis telifatının bulunup bulunmamasına göre tasnif edildiği eserde müellif hadis telifatı bulunan fakihler başlığı altında İbn Balaban (ö. 739/1339), Moğultay b. Kılıç (ö. 762/1361), Alâüddîn İbnü’t-Türkmânî (ö. 750/1349), Yusuf ez-Zeylaî (ö. 762/1360), Bâbertî (ö. 786/1384), Kureşî (ö. 775/1373), Bedrüddîn el-Aynî (ö. 855/1451) ve Kāsım b. Kutluboğa'nın (ö. 879/1474) hayat hikâyeleri ile fikıh ve hadis alanlarındaki eserleri nakletmekte ve ekol içerisindeki yerlerini değerlendirmektedir. Hadis telifatı bulunmayan fakihler grubunda ise Ebü'l-Abbâs es-Serûcî (ö. 710/1310), Osman b. Ali ez-Zeylaî (ö. 743/1343), Ömer b. İshâk el-Gaznevî (ö. 773/1372), İbn Ebü’l-İz (ö. 792/1390) ve İbnü'l-Hümâm (ö. 861/1457) ele alınmaktadır. Ekolün temel özelliklerinin ele alındığı ikinci alt başlıkta Mısır Hanefîlerinin mezhep içerisinde daha önce görülmemiş bir şekilde hadis ilmiyle ilgilenerek "hadisçi damar" diye tavsif edilebilecek bir janra sahip oldukları ifade edilmiş ve ekolün özellikleri yedi başlıkta tetkik edilmiştir. Bunlardan ilki olarak mezhebin önde gelen eserlerinde yer alan hadislerin tahrîcinin yapılması gösterilmiştir. Nitekim Mısır Hanefîliğine mensup fakihler, mezhepte otorite haline gelen eserlerin hadislerini tahrîc etmiş ve bunların kritiğini yapmış, böylece mezhebin hadislerle güncellenmesi sağlanmıştır. Çalışmada Mısır Hanefîliğinin ikinci ve üçüncü özelliği olarak hadis şerhleri ve ricâl eserleri yazımı zikredilmiştir. Hadis şerhi yazımının daha önce mezhepte görülmeyen ve Mısır Hanefî fukahâsı tarafından başlatılan bir faaliyet olduğunu belirten müellif aynı zamanda bu fakihlerin hadisle olan meşguliyetlerinden ötürü pek çok ricâl eseri yazdıklarını da ifade etmektedir. Ekolün dördüncü özelliği olarak Mısır Hanefîlerinin hadis alanında otorite olan âlim ve eserlerine itibar etmekle birlikte zaman zaman bunları tenkit etmeleri sayılmıştır. Eserde zikredilen diğer iki özellik de mezhebi hadisle destekleme ve mezhep savunusu yapmaktır. Mezhebin teşekkülünden sonra başlayan ve müteahhirîn dönemine kadar devam eden mezhebi hadisle teyit etme anlayışının müteahhirîn ile inkıtaya uğradığını ileri süren yazara göre bu çaba Mısır Hanefîleri ile tekrar başlamıştır. Ayrıca bu dönem fakihleri özellikle Ebû Hanîfe ve Tahâvî şahsında mezhebe yöneltilen tenkitleri de yine hadisler aracılığıyla berhava etmeye çalışmış, diğer mezheplere karşı Hanefîliği savunmada hadis ilmine müracaat etmişlerdir. Mısır Hanefîliğinin temel özelliklerinden sonuncusu olarak fikhî faaliyetlerde hadis merkezli düşüncenin rolünün gösterildiği eserde bu rol; mezhep içi tercihlerde ve mezhep görüşüne muhalefette hadisin 
rolü olarak iki kısımda incelenmiş, Hanefî fakihlerin hadisler lehine mezhep içi görüşlerde bulunduğu ve mezhep görüşüne dahi muhalefet edebildikleri vurgulanmıştır.

Eserin üçüncü ve son bölümünde Mısır Hanefîliğinin mezhep içerisindeki etkisi; Osmanlı dönemi Mısır-Şam havzası, Osmanlı dönemi Anadolu havzası ve Hint alt kıtası özelinde değerlendirilmiştir. Mısır Hanefîliğinin Memlüklerin yıkılıp bölgenin Osmanlı hâkimiyetine girmesinden sonra dahi devam ettiğini ancak bu etkinin zamanla azaldığını belirten müellif Mısır Hanefîliğinin son temsilcisi olarak hadis merkezli fıkıh anlayışını önemli ölçüde koruyan İbn Âbidîn’i göstermektedir. Bununla birlikte Misır Hanefîliğinin erken dönem Osmanlı ulemâsını derinden etkilediği savı Şeyh Edebâli (ö. 726/1326), Dâvûd-i Kayserî (ö. 751/1350), Şeyh Bedreddin (ö. 823/1420) ve Molla Fenârî (ö. 834/1431) gibi Mısır coğrafyasında tahsil gören pek çok âlim ve eserleri üzerinden temellendirilmeye çalışılmış, aynı zamanda iki dönem arasındaki benzer ve farklı noktalara değinilmiştir. Son olarak eserde Mısır Hanefîliğinin Hint alt kıtasını etkilediği ancak bu etkinin doğrudan değil Mısır'da eğitim alan ve daha sonra bu bölgelere giden âlimler ve Mısır Hanefî fukahâsının eserleri aracılığıyla olduğu belirtilmektedir.

Sonuç olarak akademik araştırmaları çoğunlukla Mısır Hanefîliği üzerinde yoğunlaşan Karadağ'ın bu ekolün teşekkül sürecini, mahiyetini ve temel özelliklerini konu edinen ilgili eseri bu ekole 1şık tutması açısından İslâm hukuk literatürüne önemli bir katkıda bulunmaktadır. Bu alanda çalışma yapmak isteyen araştırmacılar için kıymetli bilgiler ve değerlendirmeler içermektedir. Kimi yerlerde yapılan imla hatalarına rağmen müellifin yalın dili ve üslubu eseri daha akıcı hale getirmiştir. Ayrıca ana ve alt başlıkların tutarlı bir sistematik içerisinde ele alınması ve muhteva ile de uyumlu olması eserin titiz bir çalışmanın ürünü olduğunu göstermektedir. 
